\title{
Absence of Renal Protection of an Aqueous Extract of Lemongrass (Cymbopogon citratus) Cultivated in Costa Rica, Using a Model of Acute Renal Failure in Wistar Rats
}

\section{Apú Leitón Navilla*1,3, Fallas Ramirez Jose Manue12,3, Orozco Aguilar Josué1, 3, Rodriguez Arrieta Jesús Alexander ${ }^{4}$, Mora Román Juan José2, 3}

1Pharmacology, Toxicology, and Pharmacodependence Department, Pharmacy Faculty, Universidad de Costa Rica, San José, Costa Rica.

2Industrial Pharmacy Department, Pharmacy Faculty, Universidad de Costa Rica, San José, Costa Rica.

3Instituto de Investigaciones Farmacéuticas (INIFAR), Pharmacy Faculty, Universidad de Costa Rica, San José, Costa Rica.

${ }^{4}$ Centro de Investigación en Estructuras Microscópicas (CIEMic), Universidad de Costa Rica, San José, Costa Rica.

\begin{abstract}
A B S T R A C T
C. citratus, known as zacate de limón (lemongrass), is commonly used in Costa Rica for the treatment of "kidney diseases." Therefore, the activity as renal protector of an aqueous extract of this plant was evaluated after oral administration, in a model of acute kidney injury (AKI) in female Wistar rats. For this, an aqueous extract was characterized by thin layer chromatography and qualitative phytochemical tests. An AKI model induced by potassium chromate in female Wistar rats was carried out. The serum concentration of creatinine, sodium, potassium and glucose were determined, as well as the concentrations of creatinine, sodium, potassium, glucose and proteins in urine, together with the urinary flow determination. A histopathological analysis of the subjects' kidneys was performed, and the presence of kidney damage was identified. The characterization of the extract by thin layer chromatography, and ferric chloride, Shinoda and Wilson tests gave negative results for phenols, tannins and flavonoids. No positive changes were observed in renal function markers in urine. No histopathological evidence of nephroprotective activity of the aqueous extract of $C$. citratus was found. It is concluded that the aqueous extract of $C$. citratus obtained by infusion does not possess nephroprotective activity at a dose of $150 \mathrm{mg} / \mathrm{kg}$ evaluated by the AKI in female Wistar rats.
\end{abstract}

Keywords: Acute renal failure, potassium chromate, lemongrass, phytochemistry, nephroprotection, Wistar rats.

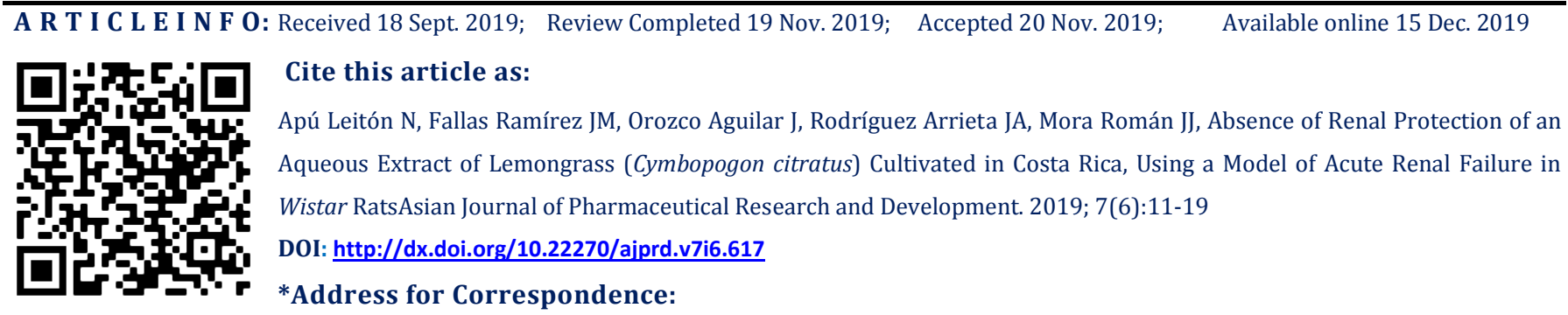

Apú Leitón Navilla, Pharmacology, Toxicology, and Pharmacodependence Department, Pharmacy Faculty, Universidad de Costa Rica, San José, Costa Rica

\section{INTRODUCTION}

A $\mathrm{KI}$ is a clinical syndrome that occurs through a rapid decrease in glomerular filtration, this over the course of hours or days. It is usually accompanied by an increase in the serum concentration of creatine, the accumulation of metabolic acids, an increase in the concentration of phosphate and potassium, and a decrease in the excretion of urine ${ }^{1-4}$. In recent years, studies have been conducted in the United States, where an increase in the incidence rate of the AKI has been seen. An increase of 61 to 288 cases per 100,000 inhabitants between 1988 and 2002 has been reported ${ }^{5}$. In addition, in Scotland in 2003 there was a report of 1,811 cases per million inhabitants ${ }^{6}$. 
At present there is no specific pharmacological treatment for this disease, so some sectors of the population have tried to seek new therapeutic alternatives against this disease. An example of this is the use of medicinal plants whose use over the years has been frequent in Costa Rica, since it has long been the doctor's only resource for treating a condition ${ }^{7}$. In this country, there is an extensive amount of plants used in medicine; thanks to the great biodiversity it has. However, the scientific literature that supports these uses is small ${ }^{8}$, one of which is $C$. citratus. Although some authors suggest that C. citratus has nephroprotective properties, others indicate that it is nephrotoxic and acts in a similar way to loop diuretics $^{9-11}$.

C. citratus, commonly known as zacate de limón (in Costa Rica), is native to southwestern Asia. Currently, it can be found in different areas, covering both neo and intertropical regions. It easily develops in hot and humid areas, with rainfall of 250 to $330 \mathrm{~cm}$ per year and a temperature that ranges between 20 and $30{ }^{\circ} \mathrm{C}^{12,13}$. Its growth occurs in dense clusters that can reach a height of $1.8 \mathrm{~m}$ and a width of approximately $1.2 \mathrm{~m}^{14}$. It has traditionally been used in the preparation of food, due to its flavor, in the perfumery and cosmetics industry (for its lemon essence), and in traditional medicine, for the various properties that have been attributed to it $^{12,15}$. Its use as a drug is due to the effects it produces, thanks to its secondary bioactive components which vary according to the geographical area of origin, the age of the plant used, the extraction method, the time of collection and the section of the plant employed. Some of the main compounds found are tannins, saponins, flavonoids, alkaline phenols and anthraquinones ${ }^{9}$.

Therefore, the objective of the present investigation was to evaluate the activity as renal protector of an aqueous extract of $C$. citratus after its administration in an AKI model in female Wistar rats.

\section{MATERIALS AND METHODS}

\section{Reagents}

Potassium chromate, Bradford's reagent, and serum creatinine, glucose, and bovine albumin standards were Sigma-Aldrich ${ }^{\circledR}$ brand. The kits for glucose and creatinine were Randox ${ }^{\circledR}$. The reagents for the phytochemical analysis were polyphenone 60 and caffeic acid from Sigma-Aldrich ${ }^{\circledR}$ and quercetin dihydrate from Fluka ${ }^{\circledR}$.

\section{Vegetal material}

Leaves of $C$. citratus were collected at the Escuela de Agronomía de la Región Tropical Húmeda (EARTH University), located in Mercedes, Limón (10¹3'09"N $\left.83^{\circ} 35^{\prime} 33^{\prime \prime} \mathrm{W}\right)$. The collected samples were determined by the botanist Dr. Carlos Morales of the Universidad de Costa Rica (UCR) and were deposited in the herbarium of the School of Biology of the UCR, following the procedural standards of the UCR Commission on Biodiversity.

\section{Aqueous extract preparation and characterization}

It was carried out in the Laboratorio de Fitofarmacología y Tecnología Farmacéutica y Cosmética (LAFITEC) of the Pharmacy Faculty of the UCR. The extract was prepared by infusion. For this, $60 \mathrm{~g}$ of dried and ground leaves were taken with a standard WILEY MILL mill No. 0.3 , and $500 \mathrm{ml}$ of boiling water were added. Subsequently, the mixture was allowed to stand in a glass container with a lid for 30 minutes. After this period, the infusion was decanted, and the volume was reduced by a Büchi R-134 rotavapor. Finally, it was lyophilized using the LAZONON® FreeZone freeze dryer.

The characterization of the aqueous extract was carried out by thin-layer chromatography and supplemented by phytochemical tests to evaluate the presence of tannins, flavonoids and phenols ${ }^{16}$. Silica gel plates were used and as mobile phase a solution of toluene-ethyl acetate-formic acid $(5: 4: 1)^{17}$. The development was made with the naked eye and with ultraviolet light $(256 \mathrm{~nm})$ for the flavonoids. For this, $\mathrm{FeCl}_{3} 10 \%$ was used for tannins, $\mathrm{AlCl}_{3} 1 \%$ in ethanol for flavonoids and sulfuric acid $5 \%$ in ethanol together with vanillin $1 \%$ in ethanol for phenols ${ }^{18,19}$. The standards used were polyphenone 60 from green tea for phenols, caffeic acid for phenols and quercetin dihydrate for flavonoids.

The phytochemical test carried out included the Shinoda and Wilson tests for flavonoids and the $\mathrm{FeCl}_{3}$ test for phenolic compounds ${ }^{16,20}$. The Shinoda test was done by adding a metallic magnesium chip and 5 drops of concentrated $\mathrm{HCl}$ to $2 \mathrm{ml}$ of aqueous extract. In addition, distilled water was used as blank and quercetin as reference standard ${ }^{16}$.

For the Wilson test, $1 \mathrm{ml}$ of aqueous extract was mixed with $2 \mathrm{ml}$ of Wilson reagent (boric acid and citric acid, both $5 \%$, in acetone). Distilled water was used as blank and quercetin as reference standard ${ }^{20}$.

In relation to the ferric chloride test, $2 \mathrm{ml}$ of aqueous extract was mixed with 5 drops of $\mathrm{FeCl}_{3} 10 \%$. Distilled water was used as blank and quercetin as reference standard ${ }^{16}$.

\section{Biologic material}

Wistar Hannover adult female rats (HsdBriHan: WIST) of $200 \pm 14 \mathrm{~g}$ of body weight, reared in the Laboratorio de Ensayos Biológicos (LEBi) of the UCR, were used. The trial was approved by the Comité Institucional para el Cuidado y Uso de los Animales (CICUA) on the official letter 018-16. The animals' handling and care was done following the procedures of the Guía para el cuido y uso de animales de laboratorio of the UCR, which develops the provisions established in the law 7451 (Animal Welfare). They were maintained in the conditions of the bioterium (constant temperature of 22 to $24{ }^{\circ} \mathrm{C}$, relative humidity of 60 to $70 \%$, and light and dark cycles of 12 hours) for adaptation during 7 days before the biological test, with access to water (Members selection®) and food (Aguilar \& Solís®) $a d$ libitum.

\section{Lyophilized dose determination}

The administered dose to each animal corresponded to 150 $\mathrm{mg}$ of lyophilisate per $\mathrm{kg}$ of rat weight per oral route. A higher dose was used in comparison to that employed in previous studies $^{21}$ to observe the effect of the plant, considering the maximum doses allowed by the Programa Iberoamericano de Ciencia y Tecnología para el Desarrollo 22 . 


\section{Experimental design}

After the adaptation period, the rats were weighed and distributed randomly in 4 groups of 5 rats each. A first group called control without AKI (group 1, negative control), a second group to which the AKI was induced (group 2, positive control), a third group to which the AKI was induced and subsequently received a daily dose during 4 days of the extract (group 3, AKI + Tx), and a fourth group that was treated with the extract 3 hours before the induction of the AKI and subsequently received a daily dose for 4 more days of the same extract (group 4, AKI + PTx).

The biological test lasted 4 days, during which the animals had access to food and water ad libitum. On day one, animals from the control group without AKI received a dose of 250 $\mu l$ of sterile water for injection subcutaneously (vehicle). The other animals (groups 2 to 4 ) received a single dose of 20 $\mathrm{mg} / \mathrm{kg}$ of potassium chromate from Sigma-Aldrich® in Baxter ${ }^{\circledR}$ physiological saline solution for injection, subcutaneously to induce $\mathrm{AKI}^{23}$. The animals of group 4 received 3 hours before the induction of the AKI, a dose of $150 \mathrm{mg} / \mathrm{kg}$ orally, of the lyophilizate solution of the extract. On days $1,2,3$, and 4 of the experiment, the animals of the control group without AKI and the AKI group received a dose of $2 \mu \mathrm{l} / \mathrm{g}$ of water weight (vehicle) orally, while those of groups 3 and 4 received a dose of $150 \mathrm{mg} / \mathrm{kg}$ (equivalent to 2 $\mu \mathrm{l} / \mathrm{g}$ of weight) of the lyophilized solution of the extract. On day 5 and after the administration of the vehicle or the extract last dose, the animals were placed in metabolic cages for a period of 8 hours, to collect urine from that period. This was separated into fractions of $750 \mu \mathrm{l}$ and frozen at $-70{ }^{\circ} \mathrm{C}$ until analysis.

Once this collection period had elapsed, the total blood of the animals was extracted using the decapitation technique. The blood was centrifuged at $3000 \mathrm{rpm}$ using a Hettich ${ }^{\circledR}$ Universal 320/320R centrifuge for 10 minutes to separate the serum, which was collected in $500 \mu \mathrm{l}$ fractions and frozen at $-80{ }^{\circ} \mathrm{C}$ until analysis.

\section{Renal protection evaluation}

The following markers of renal functioning were determined in the four groups of animals: creatinine, sodium, potassium and serum glucose concentrations, creatinine, sodium, potassium, glucose and protein levels in urine, and urine flow (UF). Subsequently, glomerular filtrate rate (GFR), as well as urinary excretions of sodium (UENa), potassium (UEK) glucose (UGE) and protein (UPE) were calculated ${ }^{23}$.

The concentrations of creatinine in serum and urine were determined colorimetrically, using the Randox ${ }^{\circledR}$ kit for the determination of this substance ${ }^{23}$.

The serum and urinary concentrations of sodium and potassium were measured at the Departamento de Análisis Clínico (DAC) of the Faculty of Microbiology of the UCR with the help of the Roche ${ }^{\circledR}$ AVL 9180 electrolyte analyzer. Subsequently, the electrolyte balance was determined by the calculation of the purification, the urinary excretion, the fractional excretion and the filtered load of both sodium and $\operatorname{potassium}^{23,24}$.
The glucose concentration in serum and urine was measured by the ultraviolet GLUC-HK method with the Randox ${ }^{\circledR}$ kit for glucose determination ${ }^{25,26}$. Finally, the total proteins in urine were measured following the Bradford method ${ }^{27}$.

\section{Histopathological analysis of the kidneys}

After the application of euthanasia, both kidneys were extracted to all experimental animals. They were fixed in formalin $10 \%$ in the presence of a phosphate buffer and embedded in paraffin to obtain thin sections at $4 \mu \mathrm{m}$ thickness, with transversal and longitudinal sections. Subsequently, they were stained with hematoxylin-eosin following conventional protocols ${ }^{28}$. The histopathological protocols were carried out in the CIEMic of the UCR. For each kidney, evidence of kidney damage induced by potassium chromate was identified. The photographs were obtained in a Zeiss AxioLab microscope adapted with a 5megapixel camera and processed by Zen lite software from Zeiss®.

\section{Statistical analysis}

The results were expressed as the mean along with the standard error of the mean. Parametric tests were carried out by using the IBM ${ }^{\circledR}$ SPSS ${ }^{\circledR}$ Statistics 23 program. The statistical difference between groups was calculated by a one-way ANOVA and the comparison of means between groups was done by the Tukey post-hoc method, with $95 \%$ significance level significance. Both analyzes were performed in the GraphPad Prism 6 program.

\section{RESULTS AND DISCUSSION}

The AKI induction by potassium chromate causes kidney damage at the tubular level, since in the chromium metabolization, reactive species that interact with membrane and intracellular proteins are produced in the tubules, altering the reabsorption and the secretion processes ${ }^{23}$. In this way, the process of tubular necrosis is induced. In Wistar rats, as in humans, the toxicity of chromium is determined by its high renal excretion, its oxidation state (the reduction of $\mathrm{Cr}^{+6}$ to $\mathrm{Cr}^{+3}$ is responsible for the production of reactive species) and the solubility of its compounds $\left(\mathrm{Cr}^{+6}\right.$ is easier to absorb compared to $\left.\mathrm{Cr}^{+3}\right)^{29-32}$.

\section{Characterization of the aqueous extract by phytochemical screening}

An aqueous extract of $C$. citratus was obtained by infusion, with a recovery percentage of $7.51 \%$.

In the characterization carried out, it was found that when the chromatographic plate was revealed with $\mathrm{AlCl}_{3}$, the result was negative for flavonoids with respect to the quercetin standard used. As a complement, with $\mathrm{FeCl}_{3}$ as a visualization reagent, the presence for tannins was not found in comparison to the polyphenone 60 from green tea standard. Likewise, when using vanillin and sulfuric acid to reveal phenols, the test was also negative when the comparison was made with respect to the caffeic acid standard. These results were also reflected in the phytochemical tests of ferric chloride, Shinoda and Wilson, as they were negative for the three cases. This coincides with previous studies where flavonoids and tannins have not been 
found and a small amount of phenols has been observed in the aqueous extract ${ }^{33,34}$.

Regarding the model used, previous studies have shown that a single dose of potassium chromate is sufficient to generate physiological alterations in the subjects' kidney, such as changes in GFR and an increase in serum creatinine; which occur between days 3 and 5 after the induction of insufficiency $^{23,29,31}$.

In relation with the GFR, a significant decrease in creatinine clearance was found in the rats treated and pretreated with $C$. citratus compared to the control group without AKI after 4 days of treatment with a dose of $150 \mathrm{mg} / \mathrm{kg}$ of aqueous extract of $C$. citratus. However, no significant differences were found with respect to the control group with AKI and neither between them, as can be seen in Figure $1 \mathbf{A}$.

The GFR by the kidney per unit of time is determined by the measurement of creatinine clearance, since this compound is freely filtered at the glomerular level and suffers very little tubular handling ${ }^{35}$. In the presence of kidney damage, it tends to decrease, because of the alteration of the filtration processes $^{3,4}$. In addition, consequently, the serum creatinine
Variation of renal function and kidney damage markers

concentration tends to increase in the sick subjects, since the renal capacity is not available to eliminate it, accumulating in the blood ${ }^{35}$.

Therefore, there is no evidence of a decrease in the renal damage in both the AIK + Tx and AIK + PTx groups, unlike that found in the literature. In Wistar rats, it was demonstrated that an ethanolic extract of $C$. citratus did not generate significant alteration in the serum concentration of creatinine $^{11}$. As a complement, in Sprague Dawley, rats no significant change was obtained after the chronic administration of an infusion of this plant ${ }^{36}$, whereas in male albino rats, previously treated for six days with an aqueous extract of $C$. citratus before the AIK induction with cisplatin, significant differences were observed regarding the control with AIK in the serum creatinine values, which indicates a nephroprotective effect of the aqueous extract ${ }^{37}$. In contrast, there is evidence of a decrease in glomerular filtration in humans after the administration of a chronic treatment of an infusion of $C$. citratus $^{38}$, in agreement with the results obtained.

A

B

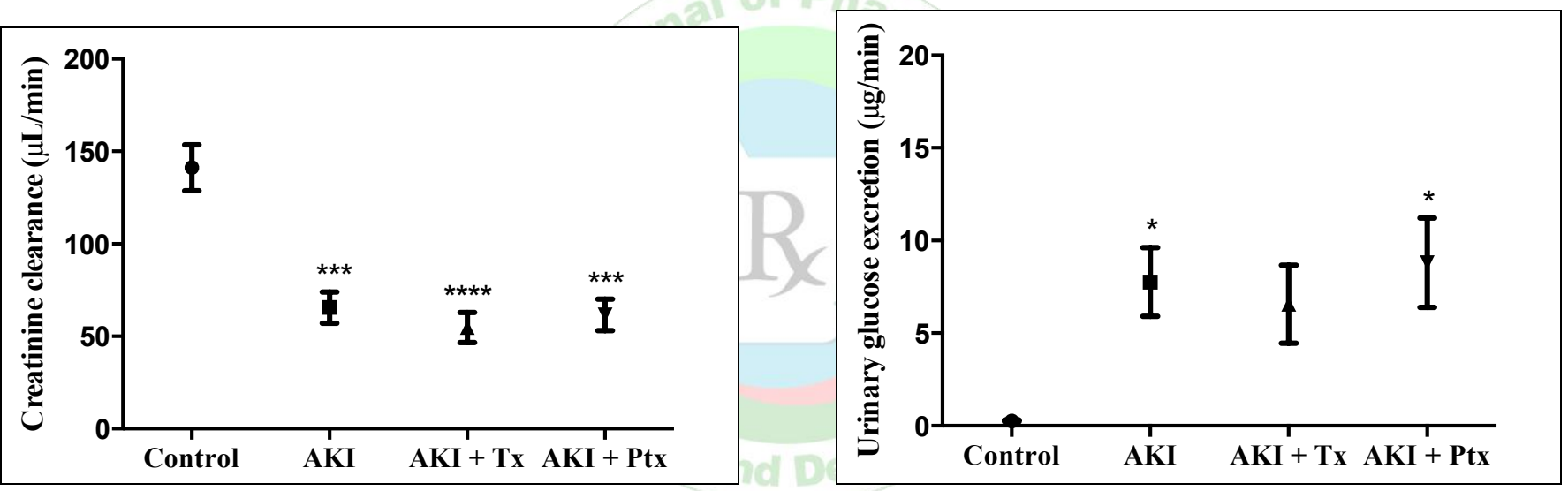

C

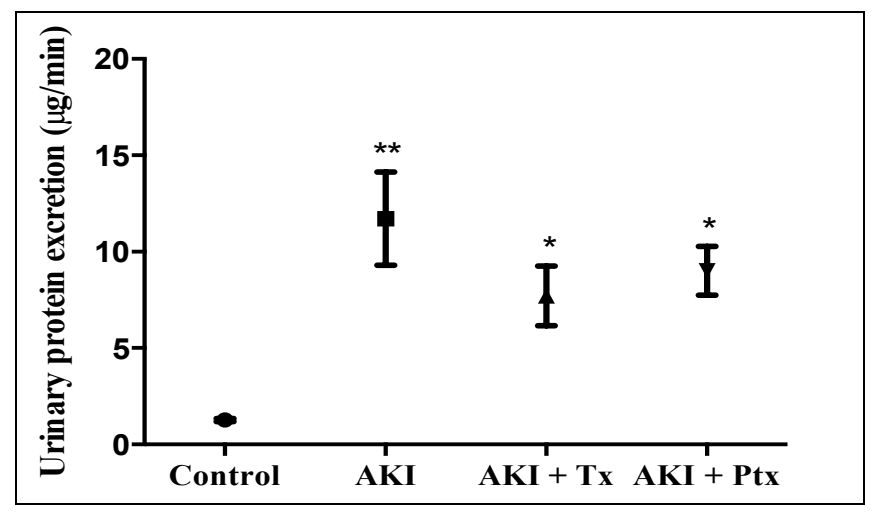

Figure 1. Variation of creatinine, glucose and protein clearance in female Wistar rats treated and pre-treated with aqueous extract of $C$. citratus. A. The AKI, $\mathrm{AKI}+\mathrm{Tx}$, and AKI + PTx groups showed a decrease in creatinine clearance compared to the control group. B. AKI and AKI + PTx groups showed a significant increase in urinary glucose excretion, compared to the control group, while there was an upward trend for the AKI + Tx group. C. The AKI, AKI + Tx, and AKI + PTx groups showed a significant increase in urinary protein excretion with respect to the control group. The average of the values obtained for each treatment is shown along with the respective standard mean error. The results were analyzed by one-way ANOVA $* * * * \mathrm{p}<0.0001$, *** $\mathrm{p}<0.001, * * \mathrm{p}$ $<0.01, * \mathrm{p}<0.05$, five rats per group, except in the AKI + Ptx group that was worked with 4 subjects. 
On the other hand, a parameter frequently used to assess renal failure is the glucose reabsorption in the kidneys, given by active glucose transporters located in the proximal tubule $^{39}$. Glucose is reabsorbed $100 \%$ under normal conditions, so it is not usually found in urine unless there is damage at the level of this tubule ${ }^{40}$. The determination of the urinary glucose concentration and its excretion are markers of the nephron reabsorption function ${ }^{41}$.

Our results showed that the glucose excretion (Figure 1B) was significantly increased in the AKI and AKI + Ptx groups compared to the control group without AKI, which presented excretions very close to 0 . In the $\mathrm{AKI}+\mathrm{Tx}$, there was a tendency to increase in relation to negative control. Also, among the groups with treatment and pre-treatment with $C$. citratus, there were no significant differences. These increases are clear evidence of lesions in the proximal tubule. It has been shown that in female Wistar rats, when inducing AIK by dichromate, the concentration of urinary glucose undergoes a constant increase ${ }^{41,42}$. Since there were no differences in urine concentration and glucose excretion in the treatment and pre-treatment groups with $C$. citratus and the AIK group, it is not possible to consider that the aqueous extract of this plant possesses nephroprotective activity. Otherwise, a significant decrease in these values with respect to the positive control would have been expected, as has been demonstrated previously with other extracts in the animal model used ${ }^{30,43}$.

Finally, the presence of proteins in urine was evaluated, since low molecular weight proteins degradation and absorption occurs mainly in the proximal tubule. The low molecular weight proteins absorption is given by peptidases of the brush border membrane present in this tubule. As a complement, those of high molecular weight are absorbed by endocytosis, taken to the proximal tubule and introduced in lysosomes for their degradation ${ }^{44}$. The induction of AIK by chromate causes damage to the brush border membrane, due to the free radicals' action, losing the capacity of protein resorption $^{32,45}$. For this reason, it is common to find proteins in the glomerular filtrate (proteinuria), and its presence has been commonly used as a marker of AIK. In addition, it occurs during the first 4 days after induction with potassium chromate $^{41,42}$.

Significant increases in urinary excretion were found in the groups treated with the aqueous extract compared to the control group without AIK and no significant differences were found with respect to the positive control. This information is shown in Figure 1C.

Consequently, this parameter also shows the non-existence of nephroprotection of the aqueous extract of $C$. citratus. The expectation was to find a significant decrease in this parameter because in the animal model of AIK used, the nephroprotective activity is exhibited by a decrease in urinary protein excretion ${ }^{23,30,41}$. These results differ from what was found in previous studies; for example, in rabbits with AIK induced by gentamicin, it was observed as this plant caused a significant reduction in urinary protein excretion $^{10}$ and in Wistar rats, it was reported that an ethanolic extract of $C$. citratus did not significantly alter the protein excretion with respect to the group without AIK $^{11}$.

Regarding the water balance, the findings are summarized in Table 1. The tubular handling of sodium and potassium electrolytes is done throughout the nephron. However, at proximal tubule level, its reabsorption is greater ${ }^{42}$. The proximal tubule is characterized by having a layer of cells that has microvilli at the luminal border, increasing the surface area of salt, water and other molecules reabsorption, and generating high permeability for electrolytes such as sodium and potassium ${ }^{46-48}$. Sodium reabsorption is carried out by active transport through the sodium-potassium pump powered by ATP, through a positive gradient for potassium reabsorption by diffusion ${ }^{49,50}$. It has been indicated that the induction of AIK with chromate, by acting on the proximal tubule, decreases the reabsorption processes of sodium and potassium, altering the electrolyte balance of the individual. Therefore, it seeks to compensate the balance by reducing the clearance of these ions ${ }^{23,41,42}$.

Table 1: Variation of the electrolyte balance in female Wistar rats treated and pre-treated with aqueous extract of $C$. citratus

\begin{tabular}{|c|c|c|c|c|c|c|c|c|}
\hline Group & $\begin{array}{l}\begin{array}{l}\text { Sodium } \\
\text { depuration }\end{array} \\
(\mu \mathrm{L} / \mathrm{min})\end{array}$ & $\begin{array}{l}\text { Potassium } \\
\text { depuration } \\
(\mu \mathrm{L} / \mathrm{min})\end{array}$ & $\begin{array}{l}\text { Urinary } \\
\text { sodium } \\
\text { excretion } \\
(\mu \mathrm{mol} / \mathrm{min})\end{array}$ & $\begin{array}{l}\text { Urinary } \\
\text { potassium } \\
\text { excretion } \\
\text { ( } \mu \mathrm{mol} / \mathrm{min})\end{array}$ & $\begin{array}{l}\text { Fractional } \\
\text { sodium } \\
\text { excretion }\end{array}$ & $\begin{array}{l}\text { Fractional } \\
\text { potassium } \\
\text { excretion }\end{array}$ & $\begin{array}{l}\text { Filtered } \\
\text { sodium load } \\
(\mu \mathrm{mol} / \mathrm{min})\end{array}$ & $\begin{array}{l}\text { Filtered } \\
\text { potassium } \\
\text { load } \\
(\mu \mathrm{mol} / \mathrm{min})\end{array}$ \\
\hline Control & $4.096 \pm 0.325$ & $186.5 \pm 14.8$ & $\begin{array}{l}0.6185 \pm \\
0.0490\end{array}$ & $1.119 \pm 0.089$ & $2.922 \pm 0.164$ & $133.1 \pm 7.4$ & $\begin{array}{l}0.0214 \pm \\
0.0019\end{array}$ & $\begin{array}{l}0.00085 \pm \\
0.00007\end{array}$ \\
\hline AKI & $1.007 \pm 0.164$ & $169.4 \pm 27.7$ & $\begin{array}{l}0.1551 \pm \\
0.0253\end{array}$ & $\begin{array}{l}0.9996 \pm \\
0.1631\end{array}$ & $1.528 \pm 0.200$ & $257.1 \pm 33.7$ & $\begin{array}{l}0.0102 \pm \\
0.0014\end{array}$ & $\begin{array}{l}0.00038 \pm \\
0.00005\end{array}$ \\
\hline $\mathbf{A K I}+\mathbf{T x}$ & $3.672 \pm 0.845$ & $153.7 \pm 35.4$ & $\begin{array}{l}0.5104 \pm \\
0.1175\end{array}$ & $\begin{array}{l}0.8456 \pm \\
0.1946\end{array}$ & $6.706 \pm 1.094$ & $280.8 \pm 45.8$ & $\begin{array}{l}0.0074 \pm \\
0.0012\end{array}$ & $\begin{array}{l}0.00030 \pm \\
0.00005\end{array}$ \\
\hline $\begin{array}{l}\text { AKI + } \\
\text { Ptx }\end{array}$ & $2.007 \pm 0.211$ & $139.5 \pm 14.6$ & $\begin{array}{l}0.2790 \pm \\
0.0293\end{array}$ & $\begin{array}{l}0.8370 \pm \\
0.0877\end{array}$ & $3.372 \pm 0.428$ & $234.3 \pm 29.7$ & $\begin{array}{l}0.0088 \pm \\
0.0010\end{array}$ & $\begin{array}{l}0.00037 \pm \\
0.00005\end{array}$ \\
\hline
\end{tabular}


Our results show that both sodium clearance and urinary sodium excretion in the AIK + Ptx group decrease significantly compared to the control group without AIK. In contrast, in the AIK + Tx group there was no significant decrease in sodium clearance and excretion in contrast to the negative control, but there was a significant decrease in relation to the positive one. Therefore, there is no evidence of nephroprotection by the aqueous extract of $C$. citratus, although there could be a regenerative effect on the part of the latter in the sodium channels in the proximal tubule when treatment is administered after the induction of AIK.

In addition, no differences were found in the potassium purification and excretion between the groups. However, there was a decrease in the groups with AIK compared to the group without AIK. This is consistent with a previous study where there were no significant differences with respect to the control group on the fourth day after induction in the model used, despite a significant decrease on days 3 and $5^{42}$.

Another parameter determined was the fractional excretion, defined as the percentage of filtered ion excreted in the urine. It has been used to estimate the renal management of cations and as a renal marker of AIK, related to its sensitivity ${ }^{23,41}$. Significant differences were observed in the fractional sodium excretion in the AIK + Tx group with respect to the other groups, which showed no differences between them, despite previous studies showing that in the presence of AIK, fractional excretion of sodium is increased ${ }^{43}, 49$. In addition, in the fractional potassium excretion, the same result was obtained as in sodium. Only the AIK + Tx group presented significant differences with respect to the control group without ARI. Therefore, the AIK + Tx group exhibits evidence of renal damage in contrast to the other groups that show no alteration in the fractional excretion of sodium and potassium.

In addition, the filtered loads of sodium and potassium of the AIK + Tx and AIK + PTx groups presented a significant decrease compared to the control group without AIK and did not present differences in contrast to the positive control. Therefore, there is no evidence of nephroprotective activity by the aqueous extract of $C$. citratus, since a smaller number of electrolytes is being filtered to compensate for kidney damage.

\section{Renal histopathological analysis}

The results of the histopathological analysis are shown in Figure 2. The AIK induction at the histological level causes characteristic alterations in renal toxicity such as the presence of pyknotic nuclei and hyaline deposits, as well as the microvilli loss in the proximal tubule ${ }^{30,45}$. AIK generates acute tubular necrosis characterized by cell death of the tubular epithelium and tubular functions alteration ${ }^{52}$.
In the kidneys' histopathological analysis of the experimental subjects, pyknotic nuclei were observed in the cells of the groups treated with the aqueous extract and the group with AIK, unlike the cells of the control group. This is evidence of the damage caused by chromate in renal tissue, as reported in previous studies in Wistar rats ${ }^{53}$, 54. In addition, no improvement was observed in the groups treated with respect to the positive control, so histologically nephroprotection was not found.

In healthy subjects, as in the group without AIK, the proteins are extracted from the circulation by glomerular filtration and then absorbed by endocytosis towards the proximal tubule. There, they are phagocytosed, the amino acids hydrolysis is produced, and then, they are returned to the circulation ${ }^{44,55}$. However, when there is a pathology in the kidney, these mechanisms are altered, causing the accumulation of amino acid residues in the tubular cytoplasm, known as hyaline depositions. They are characterized by having a variable size, a rounded shape and large amounts of eosinophils when stained with hematoxylin and eosin ${ }^{55}$. Previously, it has been shown that the kidney damage induction with chromate generates the development of hyaline depositions in the kidney tissue of Wistar rats $^{30,54}$. The histopathological results showed abundance of these depositions in the renal tissue of the subjects with treatment and pre-treatment with aqueous extract of $C$. citratus with respect to those of the negative control.

Regarding the research developed, no evidence of nephroprotection was found in the groups treated with $C$. citratus when comparing this parameter to subjects with AIK without treatment.

Another observed portion was the proximal tubule epithelium. It consists of a highly polarized cuboidal cell layer, except for the brush border membrane. This membrane is a consequence of the cells luminal side specialization, resulting in a microvilli dense population ${ }^{44}$. These microvilli are structures composed of actin that facilitate the exchange of substances between the extracellular and the intracellular medium, since they increase the cells surface $\operatorname{area}^{56,57}$. Previous studies have reported that kidney damage caused by chromium causes microvilli loss in the proximal tubule ${ }^{45}$.

Our results revealed the microvilli loss in subjects who received treatment and pre-treatment with the aqueous extract in contrast to that observed in the control group without AIK. In addition, no differences were found with respect to the positive control that evidences that the extract used of $C$. citratus possesses nephroprotective activity. All the above contradicts the results obtained in rabbits treated with an aqueous extract of the same plant material, where no kidney damage was observed ${ }^{10}$. 

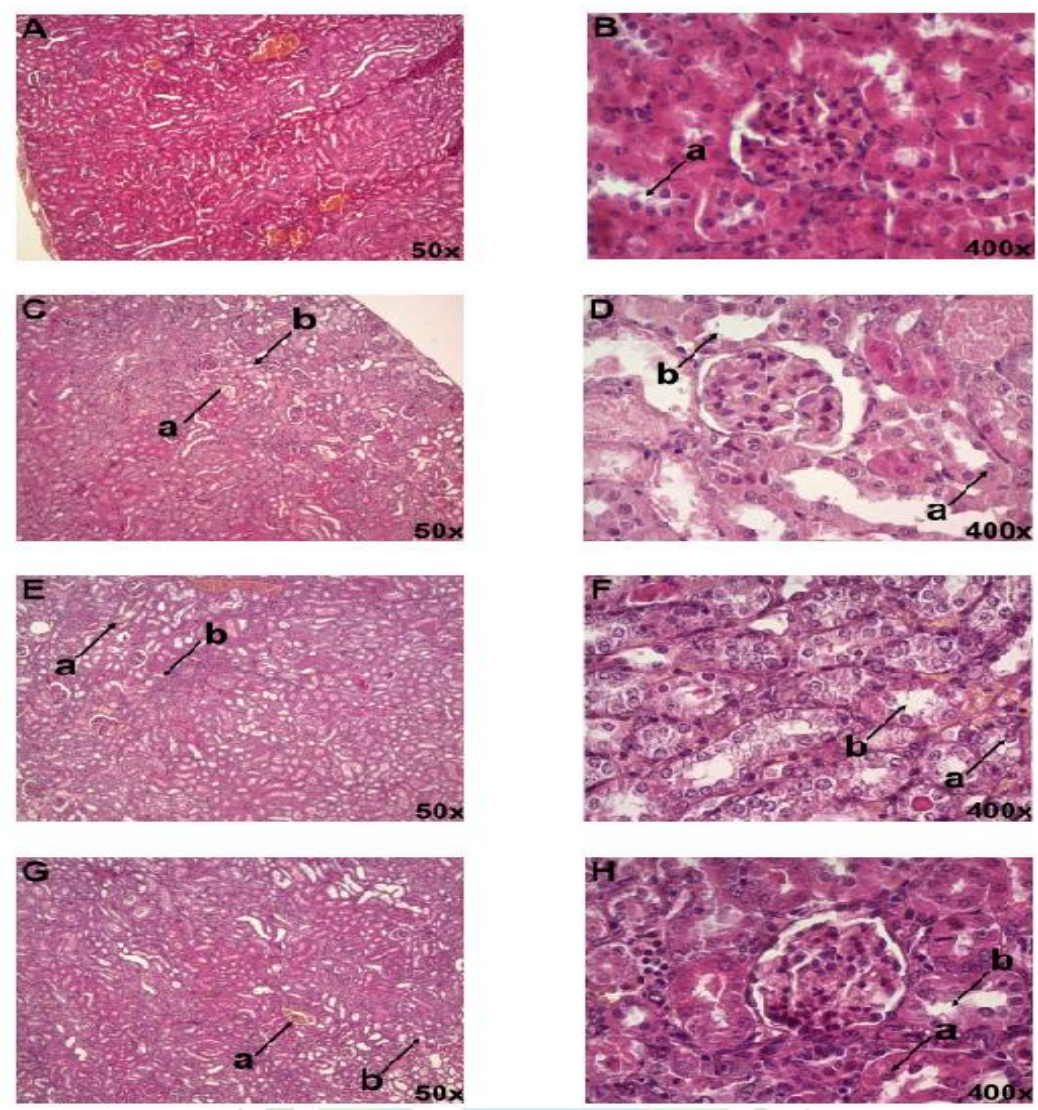

Figure 2. Histopathological findings in kidneys extracted in an AKI model induced by potassium chromate in female Wistar rats. A. Cross sections of the kidney of the control group without AKI showing renal corpuscles and tubules without alteration. B. Presence of microvilli (a) in the healthy tissue of rats in the control group without AKI. C. E. G. Cross sections of the kidney of the AKI, AKI + Tx and AKI + Ptx groups, respectively, showing hyaline deposits (a) and loss of microvilli (b). D. F. H. Presence of pyknotic nuclei (a) and loss of microvilli in the renal tissue (b) of the AKI, AKI + Tx and AKI + Ptx groups, respectively. The histopathological findings indicate that the kidney of the group without AKI is in a healthy physiological state, and the groups to which the AKI was induced present evidence of acute renal damage.

\section{CONCLUSIONS}

We sought to evaluate the activity as renal protector of an aqueous extract of C. citratus after its administration in an AKI model in female Wistar rats. The aqueous extract obtained by infusion did not contain phenols, tannins or flavonoids detectable by thin layer chromatography, and by the Shinoda, Wilson, and ferric chloride tests. In addition, the administration of a pre-treatment and a treatment with an aqueous extract of $C$. citratus did not cause significant positive differences in the markers of renal function and damage at structural level such as GFR, sodium and potassium clearance, urinary excretion of sodium and potassium, fractional excretion of sodium and potassium, filtered load of sodium and potassium, urinary excretion of glucose, and urinary excretion of proteins of the subjects treated with respect to those of the AKI group without treatment. On the other hand, the histopathological analysis of the kidneys of the experimental subjects showed the

\section{REFERENCES}

1. Monedero P, García-Fernández N, Pérez-Valdivieso J, Vives M, Lavilla J. Insuficiencia renal aguda. Rev Esp Anestesiol Reanim, 2011; 58(6):365-374.

2. Mejía CH. Insuficiencia renal aguda. Colombia Médica, 2001; 32(2):8385 presence of pyknotic nuclei, hyaline deposits and microvilli loss both in the renal tissue of the treated groups and in the AKI group without treatment, unlike the control group without AKI where those changes were not observed. For all the above, the results obtained show that there is no evidence that the aqueous extract of $C$. citratus cultivated in Costa Rica has nephroprotective activity when using a model of AKI induced by potassium chromate in female Wistar rats with the administered dose.

\section{CONFLICT OF INTEREST}

The authors declare no conflict of interest.

\section{ACKNOWLEDGMENTS}

The authors want to thank Master Rodrigo Solís for his support in the review of this paper.

3. Bellomo R, Kellum JA, Ronco C. Acute kidney injury, Lancet, 2012; 80(9843):756-766.

4. Chawla LS, Eggers PW, Star RA, Kimmel PL. Acute Kidney Injury and Chronic Kidney Disease as Interconnected Syndromes. N Engl J Med, 2014; 371(1):58-66

5. Cerdá $\mathrm{J}$, Lameire $\mathrm{N}$, Eggers $\mathrm{P}$, Pannu $\mathrm{N}$, Uchino $\mathrm{S}$, Wang $\mathrm{H}$ et al. Epidemiology of Acute Kidney Injury. Clin J Am Soc Nephrol, 2008; 3(3):881-886. 
6. Ali T, Khan I, Simpson W, Prescott G, Townend J, Smith W et al. Incidence and Outcomes in Acute Kidney Injury: A Comprehensive Population-Based Study. Clin J Soc Nephrol, 2007; 18(4):1292-1298.

7. Quesada Hernández A. Las plantas medicinales. Revista Biocenosis, 2008; 21(1-2):20-23.

8. Rodríguez Navas H. La utilidad de las plantas medicinales en Costa Rica. 2nd ed. Heredia: Editorial Universidad Nacional; 2017. 433 p.

9. Ekpenyong CE, Akpan EE, Daniel NE. Phytochemical Constituents, Therapeutic Applications and Toxicological Profile of Cymbopogon citratus Stapf (DC) Leaf Extract. J Pharmacogn Phytochem, 2014; 3(1):133-141.

10. Ullah N, Khan MA, Khan T, Ahmad W. Cymbopogon citratus Protects against the Renal Injury Induced by Toxic Doses of Aminoglycosides in Rabbits. Indian J Pharm Sci, 2013; 75(2):241-246.

11. Ademuyiwa AJ, Elliot SO, Olamide KY, Omoyemi AA, Funmi OS. Studies of the Nephroprotective and Nephrotoxicity Effects of Ethanolic Extract of Cymbopogon citratus (Lemon Grass) on Wistar Albino Rats. World J Pharm Pharm Sci, 2016; 5(12):244-256.

12. Negrelle RRB, Gomes EC. Cymbopogon citratus (DC.) Stapf: chemical composition and biological activities. Rev Bras Pl Med, 2007; 9(1):8092.

13. Nambiar VS, Matela H. Potential Functions of Lemon Grass (Cymbopogon citratus) in Health and Disease. International Journal of Pharmaceutical \& Biological Archive, 2012; 3(5):1035-1043.

14. Shah G, Shri R, Panchal V, Sharma N, Singh B, Mann AS. Scientific basis for the therapeutic use of Cymbopogon citratus, stapf (Lemon grass). J Adv Pharm Technol Res, 2011; 2(1):3-8.

15. Lawal OA, Ogundajo AL, Avoseh NO, Ogunwande IA. 2017. Cymbopogon citratus. In: Kuete V, editor. Medicinal Spices and Vegetables from Africa. London: Academic Press; 2017. p. 397-423.

16. Ekpenyong C, Daniel N, Akpan E. Phytoconstituents and diuretic activity of Cymbopogon citratus leaf infusions in humans. J Coastal Life Med, 2014; 2(9):704-713.

17. Patel AA, Amin AA, Patwari AH, Shah MB. Validated high performance thin layer chromatography method for simultaneous determination of quercetin and gallic acid in Leea indica. Rev Bras Farmacogn, 2017; 27(1):50-53

18. Reich E, Blatter A. Herbal Drugs, Herbal Drug Preparations, and Herbal Medicinal Products. In: Sherma J, Fried B, editors. Handbook of ThinLayer Chromatography. 3rd Edition. Boca Raton: CRC Press; 2003.

19. Medić-Šarić M, Jasprica I, Mornar A, Maleš Z. Application of TLC in the Isolation and Analysis of Flavonoids. In: Waksmundzka-Hajnos M, Sherma J, Kowalska T, editors. Thin Layer Chromatography in Phytochemistry. Boca Raton: CRC Press; 2008. 405-423.

20. Wilson CW. A Study of the Boric Acid Color Reaction of Flavone Derivates. J Am Chem Soc, 1939; 61(9):2303-2306.

21. Vallejo E, Weng N. Evaluación de la actividad diurética y antimicrobiana de dos plantas usadas como diuréticos en Costa Rica [thesis]. San José: Universidad de Costa Rica; 1996. 102 p.

22. Programa Iberoamericano de Ciencia y Tecnología para el Desarrollo. Manual de Técnicas de Investigación. Bogotá: CYTED; 1995. 105 p.

23. Ávila ML, Meléndez ME. El glutatión y las vitaminas C y E protegen en el daño renal agudo inducido por cromo en la rata. Revista Mexicana de Ciencias Farmacéuticas, 2009; 40(1):35-41.

24. Meléndez Camargo ME, Lozano Cortés M. Renal and hepatic interactions of acetaminophen and amikacin in the infant rat. Proc West Pharmacol Soc, 1998; 41:61-63.
25. Neeley WE. Simple Automated Determination of Serum or Plasma Glucose by a Hexokinase/Glucose-6-Phosphate Dehydrogenase Method. Clin Chem, 1972; 18(6):509-515.

26. Williams DC, Huff GF, Seitz WR. Glucose Oxidase Chemiluminescense Measurement of Glucose in Urine Compared with the Hexokinase Method. Clin Chem, 1976; 22(3):372-374

27. Bradford MM. A rapid and sensitive method for the quantification of microgram quantities of protein utilizing the principle of protein-dye binding. Anal Biochem, 1976; 72(1-2):248-254.

28. Gaviño de la Torre G, Juárez López C, Figueroa Tapia HH. 1987. Técnicas biológicas selectas de laboratorio y de campo. México: Editorial Limusa; 1987. 251 p.

29. Patel JG, Joshi DV, Patel BJ, Raval SH. Pathology of experimentally induced acute toxicity of potassium dichromate in Wistar rats (Rattus norvegicus). Indian J Vet Pathol, 2017; 41(1):75-77.

30. Khan MR, Siddiqui S, Parveen K, Javed S, Diwakar S, Siddiqui WA. Nephroprotective action of tocotrienol-rich fraction (TRF) from palm oil against potassium dichromate $\left(\mathrm{K}_{2} \mathrm{Cr}_{2} \mathrm{O}_{7}\right)$-induced acute renal injury in rats. Chem-Biol Interact, 2010; 186(2):228-238.

31. Singh AP, Muthuraman A, Jaggi AS, Singh N, Grover K, Dhawan R. Animal models of acute renal failure. Pharmacol Rep, 2012; 64(1):3144.

32. Becerra SL, Rodríguez ML, Jaramillo F, Martínez MC, Rodríguez MG, Reyes MA et al. Nefrotoxicidad producida por el cromo y actividad urinaria de la dipeptidilaminopeptidasa IV en ratas. Efecto protector de la Quercetina. Revista Mexicana de Ciencias Farmacéuticas, 2008; 39(3):5-11.

33. Shah G, Kaur M, Dhabiliya F, Shri R. Pharmacognostic Standarization of Cymbopogon citratus (dc.) stapf leaves. Pharmacogn J, 2012; 29(4):19-25.

34. Mori NC, Horn RC, Oliveira C, Gelatti GT, Klafke JZ, Tissiani AC et al. Effect of the Cymbopogon citratus Infusion on the Activity of Acetylcholinesterase Enzyme and on the Redox Profile in Farmers' Erythrocytes. J Agric Sci, 2017; 9(9): 68-77.

35. Gowda S, Desai PB, Kulkarni SS, Hull VV, Math AAK, Vernekar SN. Markers of renal function tests. N Am J Med Sci, 2010; 2(4):170-173.

36. Hanisa H, Hadijah H, Rasedee A, Tarmizi AS. Sub-acute oral administration of Cymbopogon citratus stem infusion and its effects on blood biochemical parameters, body and organ weights in rats. Journal of Tropical Agriculture and Food Science, 2011; 39(1):1-7.

37. Haggag MH. Protective Effect of Lemon Grass (Cymbopogon citratus) Water Extract Against Nephrotoxicity Induced by Cisplatin of Male Rats. Egyptian Journal of Nutrition and Health, 2015; 6(1):81-92.

38. Ekpenyong CE, Daniel NE, Antai AB. Effect of Lemongrass Tea Consumption on Estimated Glomerular Filtration Rate and Creatinine Clearance Rate. J Renal Nutr, 2015; 25(1):57-66.

39. Wright EM, Hirayama BA, Loo DF. Active sugar transport in health and disease. J Intern Med, 2007; 261(1):32-43.

40. Alsahli M, Gerich JE. Renal glucose metabolism in normal physiological conditions and in diabetes. Diabetes Res Clin Pract, 2017; 133:1-9.

41. Arreola-Mendoza L, Reyes JL, Melendez E, Martín D, Namorado MC, Sanchez E et al. Alpha-tocopherol protects against the renal damage caused by potassium dichromate. Toxicology, 2006; 218(2-3):237-246.

42. Fallas Ramírez JM. La farmacocinética del acetaminofén se modifica en ratas con insuficiencia renal aguda e insuficiencia hepática aguda [master's thesis]. Mexico DF: Instituto Politécnico Nacional; 2011. 71 p. 
43. Arreola-Mendoza L, Del Razo LM, Mendoza-Garrido ME, Martin D, Namorado MC, Calderon-Salinas JV et al. The protective effect of alpha-tocopherol against dichromate-induced renal tight junction damage is mediated via ERK1/2. Toxicol Lett, 2009; 191(2-3):279-288.

44. Maunsbach $\mathrm{AB}$, Christensen EI. Functional Ultrastructure of the Proximal Tubule. Compr Physiol, 2011; 1(Suppl 25):41-107.

45. Fatima S, Arivarasu NA, Banday AA, Yusufi ANK, Mahmood R. Effect of potassium dichromate on renal brush border membrane enzymes and phosphate transport in rats. Hum Exp Toxicol, 2005; 24(12):631-638.

46. Fox SI. Fisiología humana. 14th edition. México DF: McGraw Hill; 2016.

47. Jackson EK. Fármacos que afectan la función excretora renal. In: Brunton LL, Hilal-Dandan R, Knollman BC, editors. Goodman \& Gilman: Las Bases Farmacológicas de la Terapéutica. 13th edition. Ciudad de México: McGraw-Hill; 2018.

48. Barrett KE, Barman SM, Boitano S, Brooks HL. Ganong. Fisiología médica. 25th edition. México DF: McGraw Hill; 2016.

49. Esson ML, Schrier RW. Diagnosis and Treatment of Acute Tubular Necrosis. Ann Intern Med, 2002; 137(9):744-752.

50. Palmer BF. Regulation of Potassium Homeostasis. Clin J Am Soc Nephrol, 2015; 10(6):1050-1060.
51. Palmer LG, Schnermann J. Integrated Control of Na Transport along the Nephron. Clin J Am Soc Nephrol, 2015; 10(4):676-687

52. Sancho-Martínez SM, López-Novoa JM, López Hernández FJ. Pathophysiological role of different tubular epithelial cell death modes in acute kidney injury. Clin Kidney J, 2015; 8(5):548-559.

53. Hegazy R, Salama A, Mansour D, Hassan A. Renoprotective Effect of Lactoferrin against Chromium-Induced Acute Kidney Injury in Rats: Involvement of IL-18 and IGF-1 Inhibition. PLoS ONE, 2016; 11(3): $\mathrm{e} 0151486$.

54. García-Niño WR, Tapia E, Zazueta C, Zatarain-Barrón ZL, HernándezPando R, Vega-García CC et al. Curcumin Pretreatment Prevents Potassium Dichromate-Induced Hepatotoxicity, Oxidative Stress, Decreased Respiratory Complex I Activity, and Membrane Permeability Transition Pore Opening. Evid Based Complement Alternat Med, 2013; 2013:424692.

55. Greaves P. Histopathology of Preclinical Toxicity Studies. 4th ed. United Kingdom: Academic Press; 2012. 892 p.

56. Sauvanet C, Wayt J, Pelaseyed T, Bretscher A. Structure, Regulation, and Functional Diversity of Microvilli on the Apical Domain of Epithelial Cells. Annu Rev Cell Dev Biol, 2015; 31:593-621.

57. Brown JW, McKnight CJ. Molecular Model of the Microvillar Cytoskeleton and Organization of the Brush Border. PLoS One, 2010; 5(2):e9406. 